\title{
INTERVIEW WITH JOHN SHAW AT THE 14TH ISFNR CONGRESS, 28 JULY, 2005, TARTU
}

\author{
Interviewed by Ave Tupits
}

Could you, please, say a few words about your background?

I come originally from the US, but my background in this discipline of folkloristics really began when I started working with the Scots Gaelic speaking community in Cape Breton Island, which is in Nova Scotia - New Scotland on the eastern coast of Canada. And it was really the excellent singers and storytellers in that language and also the musicians, the fiddlers, that began to arouse my interest in folklore. These people have served as the touchstone and the inspiration both for my work and also my teaching and publications ever since those days forty years ago. I was just back there last week and went around to see people, enjoyed the socializing, but also reliving days that I spent working with them. My major background in folklore is as a fieldworker and again, in my own work I often refer back to fieldwork as being the basis for important work in folklore. I do appreciate theory, but I like to see theory backed up by good solid work on the ground.

Do you have any influencers in the field of folklore, any big names that you appreciate, whose work you appreciate?

Yes, many, and the number is growing all the time. Many of these people are in my own small field of folklore which originally was situated in Western Europe. Of course, from the 19th century, some of the Gaelic population has been in North America. But from the time I was a teenager, there was an inspiration in the form of a very good Gaelic scholar in Scotland by the name of John Lorne Campbell, who invited me from America to stay on a small island with him in the Inner Hebrides in Scotland. And it was there that I became familiar with the whole idea of going out in the field and recording folklore. As I said, what really inspired me and seized my interest in the long term, was working with the people in the field, who had (and still have) such wonderful skills and the wonderful materials that have been handed down to them from generation to generation. These are, in modern terms, quite conservative communities, but to me the people are endlessly interesting. I've noticed parallels from reading works of Finnish collectors and their relations to the communities where they worked. Such formative experiences lead to an area of folklore that should 


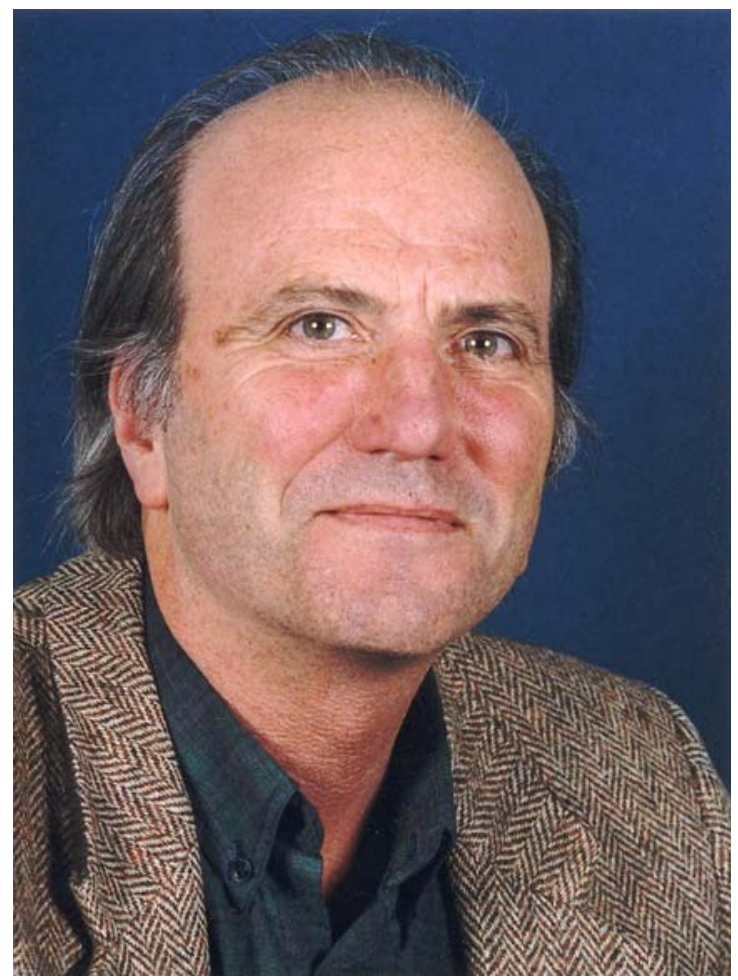

be explored much more: the dialogics that occur between folklore fieldworkers, and their co-workers who live in communities and who provide the material for the research.

\section{Would you mind sharing some vivid memories of your fieldwork through the years? Some special people or places?}

There was one storyteller by the name of Joe Neil MacNeil who was a poor itinerant worker. I think he could have become a lot richer, but he didn't really care about money. He had only a six-grade education, but his Gaelic was some of the best I've ever heard in my life. When I discovered that he could tell stories, I began to spend a lot of time with him; I was a Gaelic language teacher at the time, in this poor part of Canada, in Cape Breton. And it happened that he broke his hip - he was an older man -, and landed in the hospital. That meant that he couldn't move anywhere, so I went to visit him every day. We worked on stories and I began to see that he was a magnificent storyteller. He never sought any recognition for it, and he was never respected by the local institutions, whose orientation was toward the official languages. But we be- 
gan to work on retrieving his stories. In February 1976, he mentioned 30 stories, which he had heard about and half remembered, and by April we were able to record complete versions of seventeen of them. At the end of it, before he died, he gave me between 600 and 800 items. The specialists where I now work at the School of Scottish Studies, after they heard him, said that he was the best Scottish Gaelic storyteller living at the time. He had versions of international tales; he had legends; he had anecdotes; he knew a lot about genealogy and traditional music. His mind was like a well that, once emptied, always filled up overnight. There was always more. So he was a remarkable person. There was a woman violin player, who was known throughout the island by her Gaelic name Màiri Alasdair Raghnaill, which means - they use patronymics there - Mary, the daughter of Alexander the son of Ranald, who had a very, very powerful style and was also a Gaelic speaker. I used to listen to her as often as I could. She belonged to a larger family that I had stayed with for six months when I was younger. And I remember one of the greatest compliments she ever gave me: when I knocked on the door - she was old, she was close to eighty - her daughter answered and I could hear old Màiri asking: "Who is it?" Her daughter gave her my name and she ran to her bed, got down on her knees and pulled out her fiddle, so that she could play! So those are two unusual people, but there were literally hundreds of them.

\section{I understand that you have studied legends quite a bit and your talk here at the congress is about (e)migrating legends?}

That's right. What I'm going to talk about really has to do with the transferring of legends as part of the Gaelic diaspora, a forced migration from the western part of Scotland to the island of Cape Breton in the early 1800s. The questions that I'm going to ask and try to answer are fairly routine, but it's an interesting example of what can happen with the migration of folklore. Because we have an extensive archive in Scotland and we have a fairly large archive in Nova Scotia, we can compare the two and see what kind of legends have come across, and what kind of legends have remained in Scotland but did not survive in Cape Breton. We can also look at the creation of legends in Cape Breton based on old models, or for innovations. It seems to me that there have been some innovations in storytelling in the emigrant community, as there were in singing, which began to occur as early as a generation or two from the time of settlement. Some of these were on North American model, and may have been picked up by younger men who went out to work in the lumber camps across Canada and in the US. Others may have appeared within the community, simply as a matter of traditional consensus. These are some of the 
questions I'm going to look at in the talk and I hope that the tentative conclusions that I present there will lead to further research on the migration of folklore.

\section{I wish you a lot of luck on that!}

Well, thanks very much!

\section{Would you mind saying a few words about the position of folklore in different countries as you have been working in different countries on this side of the Atlantic Ocean and on the other side?}

I would certainly be happy to say a few words about that from my own point of view. In Scotland we are in an interesting position, because we're dealing with cultures, with indigenous cultures, which have been there for a long time. We do have a Parliament, but we don't have the advantages of political self-determination that our close neighbours in Ireland have. And this circumstance, of course, has determined, to some extent, the direction that ethnology or folklore studies have taken in Scotland. I say this because I see it as a microcosm of what's happening in many countries across the world. And what struck me both at this conference and at the last Society conference that I attended in Gottingen is how similar so many of the stories are. I'm quite interested in the position of folkloristics with regard to other academic disciplines and the way in which folkloristics as a field is regarded in universities. I see our position determined by the way in which our academic disciplines are divided up and arranged into a hierarchy, and I think it's time that we question this. Folklore is not going to disappear; it's not going to go away. The fact that it doesn't rely entirely on written records, in other words, manuscripts and printed records, and the fact that it is not exclusively concerned with the upper levels of society, to my mind does not mean it's not a legitimate academic area of study. I've had to point this out to many of my university colleagues in Scotland and elsewhere, and regard it as a fundamental point about our discipline and others that must be brought home forcefully in many parts of the world. One of the things that for me is a great morale-booster, being at a conference such as this, is the support that comes from many of our colleagues. It has come, of course, not only in terms of support after talks and so on, but also in terms of attending conferences and providing post-grads to our programs in Edinburgh, which we're trying very hard to expand and improve. Exchanges are taking place especially in Western Europe, which I think are extremely important, along with collaboration on research projects, which, again, forms bonds. These bridgebuilding initiatives are among the most effective means of asserting the importance of our field in the academic arena. 


\section{So you would say, we still have a future? Perhaps even bright future, or maybe not so bright?}

I see no reason why our future should be any less bright than anyone else's. We all like to assume that the intellectual arena must function as some form of democracy, and if we subscribe to a democratic model of the mind, then we must assume that we have an equal right to aspire to a bright future.

\section{$* * *$}

Dr. John Shaw is trained in linguistics and Celtic studies; he has conducted extensive fieldwork on Gaelic oral tradition/folklore on Cape Breton Island, Nova Scotia; he is a Gaelic language instructor, civil servant and Gaelic Development Officer in the Highlands and Islands, and also lecturer in Celtic, King's College, University of Aberdeen. His research interests include Gaelic ethnology (oral narrative, song and traditional music); social contexts of storytelling and song; native taxonomies; emigrant Scottish traditions; the interface between academic research and language/culture maintenance and development.

\section{A list of the most recent publications by John Shaw:}

Sa Chomann Ghrinn: Sùil air Seinn, Sluagh agus Coimhearsnachd in Téada Dúchais. Aistí in ómós don Ollamh Breandán Ó Madagáin. In eagar aig Máirtín Ó Briain agus Pádraig Ó Héalaí. Indreabhán: Cló Iar-Chonnachta 2002: 499-520.

What Alexander Carmichael Did Not Print: The Cliar Sheanchain, 'Clanranald's Fool' and Related Traditions. Béaloideas, 70 (2002): 99-126. ISSN 0332-270X

Oral Traditions/Folklore of Argyll in The Argyll Book. Donald Omand (ed.). Edinburgh: Birlinn 2004: 213-222.

Gaelic Cultural Maintenance and the Contribution of Ethnography. SCOTIA. Interdisciplinary Journal of Scottish Studies, 27 (2003): 35-48.

The Collectors: John Francis Campbell and Alexander Carmichael in Edinburgh History of Scottish Literature, Vol. 2. Susan Manning and Ian Brown (eds.). Edinburgh: Edinburgh University Press 2007: 347-52.

Indo-European Dragon-Slayers and Healers, and the Irish Account of Dian Cécht and Méiche. JIES 34: 153-82. 
The Blue Mountains and Other Gaelic Stories from Cape Breton / Na Beanntaichean Gorma agus Sgeulachdan Eile à Ceap Breatainn. Montreal: McGill-Queen's University Press 2007, xxi +216 pp.

Storytellers in Scotland: Context and Function. Oral Literature and Performance Culture. A Compendium of Scottish Ethnology, Vol. 9. John Beech et al.(eds.) Edinburgh: John Donald 2007: 28-41. 